\title{
O PERCURSO DA FORMAÇÃO DA LEITURA E DA LITERATURA INFANTIL NO BRASIL: UMA NOVA PERSPECTIVA A PARTIR DE MONTEIRO LOBATO
}

\author{
Renata Toigo ${ }^{1}$
}

Resumo: A literatura infantil está cada vez mais presente na sociedade contemporânea, ganhando visibilidade no âmbito dos estudos acadêmicos e manifestando-se nas relações culturais dos mais variados territórios. É preciso entender que a literatura infantil não surge como arte criada para deleite e formação do leitor infantil, mas de um longo processo de construção histórica. É no mundo contemporâneo que a literatura infantil ganha produção diversificada com qualidade ética e estética, bem como estudos e crítica literária. Para entender esse processo percorrido pela literatura infantil, faz-se necessário olhar para o percurso histórico e entender como se deu o processo de emancipação, principalmente o papel de Monteiro Lobato para com a literatura infantil, que por muito tempo foi subjugada a um subsistema literário. É Monteiro Lobato quem começa a romper com as amarras europeias e lança uma nova literatura que, por um lado, interpreta a sociedade brasileira e, por outro, está apoiada na fantasia.

Palavras-chave: Livro. Leitura. Literatura Infantil. Monteiro Lobato.

\section{O processo de formação histórica da leitura e da literatura}

A história da produção do livro é também a história do acesso à leitura por camadas da população cada vez mais diversificadas. Para entendermos como se deu a formação da leitura e literatura infantil no Brasil, é importante resgatarmos a origem do livro e as manifestações da leitura no âmbito ocidental. Nas suas origens, o símbolo escrito estava destinado à comunicação com as divindades e, com o passar do tempo, a escrita passou a ser usada entre a casta sacerdotal e os altos funcionários do poder. As técnicas de produção dos manuscritos, sejam elas sobre a argila, papiro ou pergaminho, deixavam muito caro o custo do livro. Dessa maneira, o monopólio da leitura era detido pelas altas classes da sociedade. Conforme Robine (1974), na antiguidade, os homens do campo, trabalhadores das cidades e escravos só muito excepcionalmente tinham acesso ao livro. No final do século XIII, o público leitor foi se ampliando. A nova burguesia, composta por altos funcionários públicos, ricos comerciantes e juristas, passa a desejar o livro. O crescimento do público leitor vai provocar uma pressão nas técnicas de imprensa. Em torno do ano 1440, temos com Gutemberg, a invenção da imprensa, uma

\footnotetext{
${ }^{1}$ Mestra em Letras - Teoria da Literatura pela Pontifícia Universidade Católica do Rio Grande do Sul, PUCRS, Brasil.
}

Revista de Letras JUÇARA, Caxias - Maranhão, v. 03, n. 01, p. 175 - 193, ago. 2019| 175 
grande revolução para o mundo dos livros, que deixam de ser copiados à mão e passam a ser produzidos em quantidade. Robine (1974) destaca que a imprensa se estende rapidamente por todos os países da Europa e, ao mesmo tempo que diminui o custo do livro, publicam-se também obras da literatura popular de cordel. É essa literatura de cordel mais barata que vai estabelecer a comunicação com o meio rural, por meio de vendedores ambulantes, que passam de casa em casa oferecendo o objeto livro. A autora reforça que, apesar da mecanização da imprensa, que permitiu produzir livros em maior quantidade, a aquisição do livro continuou sendo reservada à elite do dinheiro e, consequentemente, a leitura continuava como fenômeno urbano.

Para Lajolo e Zilberman (1996), a história da leitura inicia somente no século XVIII, quando a impressão deixa de ser artesanal, exercida pelos tipógrafos e gerenciada através do Estado, que facultava o aparecimento dos livros, tornandose atividade empresarial, executada em moldes capitalistas, dirigida ao lucro. As autoras ressaltam que, para a leitura se expandir e se transformar em prática social, foi preciso uma grande mudança: a valorização da família. Nesse novo modelo de família, não mais estabelecida por laços de parentesco, mas centrada nas relações de afeto, onde cabia ao pai o sustento do lar; à mãe a responsabilidade da vida doméstica, as crianças deixam de ser parte da mão de obra para serem preparadas para o futuro. Desse modo, com o surgimento da infância, os livros para as crianças ganham uma grande importância. É no interior desse modelo moderno de família que se começam a criar hábitos de leitura duradouros.

\footnotetext{
Se é certo que os leitores sempre existiram em todas as sociedades nas quais a escrita se consolidou enquanto código, (...) só existem o leitor, enquanto papel de materialidade histórica, e a leitura, enquanto prática coletiva, em sociedades de recorte burguês, onde se verifica no todo ou em parte uma economia capitalista. Esta se concretiza em empresas industriais, comerciais e financeiras, na vitalidade do mercado consumidor e na valorização da família. Foi nessas condições que os leitores, cada vez mais numerosos, se transformaram em público leitor de uma mercadoria muito específica. (LAJOLO; ZILBERMAN, 1996, p. 16)
}

Mas é somente no século XIX, com o progresso do papel e com a generalização da instrução, que o livro se põe ao alcance de mais classes sociais. É preciso entender que, apesar dessa generalização da instrução, as leis não são 
imediatas e nem para todos. Dessa maneira, o público leitor continua restrito e escasso.

É importante observar que "uma história da leitura não deve, pois, limitarse à genealogia única da nossa maneira de ler em silêncio e com os olhos, ela tem também a tarefa de encontrar os gestos esquecidos, os hábitos desaparecidos" (CHARTIER, 1994, p. 17). As maneiras de ler, assim como o percurso do livro, foram mudando ao longo dos séculos. Por muito tempo, a leitura "constituía-se numa oralização, e seu leitor aparecia como o ouvinte de uma palavra lida" (CHARTIER, 1994, p. 17). Em tempos de poucos livros, onde as jornadas de trabalho eram longas e a iluminação precária, alguém era designado para ler em voz alta para que os outros partilhassem da leitura.

Chartier (1999) destaca algumas revoluções na história da leitura, que não estão diretamente ligadas à invenção ou às transformações da impressão. A primeira consiste no longo processo que levou os leitores a passar da prática de leitura necessariamente oral para a leitura visual e silenciosa. Embora as duas maneiras de ler tivessem coexistido na Antiguidade grega e romana, foi durante a Idade Média que os leitores ocidentais conquistaram o estilo silencioso. Essa leitura silenciosa, inicialmente restrita aos monásticos, chegou às universidades durante os séculos XII e XIII e durante o século XIV tornou-se comum entre cortesãos e aristocratas laicos. A leitura silenciosa criou a possibilidade de ler mais e ler textos mais complexos.

A segunda revolução da leitura ocorreu já na era da impressão. Com o crescimento da produção do livro, tivemos a multiplicação e transformação dos jornais, o triunfo dos livros de pequeno formato e a proliferação de instituições como as bibliotecas, os clubes do livro e as sociedades de leitura, que possibilitaram a leitura de livros e periódicos sem sua compra. Os novos leitores podiam ler um grande e variado número de textos dando lugar a uma leitura mais desprendida.

A terceira revolução da leitura aconteceu no século XIX, quando novas categorias de leitores - as mulheres, crianças e trabalhadores - foram introduzidos na leitura. Isso se deu juntamente com a industrialização da produção de impressos, com novos materiais e modelos para a leitura, assim como com as políticas de alfabetização da população. 
O autor destaca, ainda, uma outra revolução que está acontecendo em nossa própria época: a transmissão eletrônica de textos, obrigando a uma profunda reorganização da escrita. As mudanças no suporte físico da escrita forçam o leitor a ter novas atitudes e aprender novas práticas intelectuais. Para o autor, a passagem do texto do livro impresso para a tela do computador, ou outras mídias, pode ser comparada com a passagem do rolo para o códex, no início da Era Cristã. Isso dita novos caminhos para a leitura que superam as limitações tradicionais impostas pelo objeto impresso. Uma das grandes vantagens é o poder de alcançar qualquer leitor, em qualquer lugar, em qualquer momento.

Saber ler, escrever, assinar e contar parecia ideal e suficiente para o povo durante o século XIX, o demais era supérfluo. De acordo com Robine (1974), no século $X X$, por meio da política cultural da redução da jornada de trabalho para oito horas diárias, férias pagas e semana inglesa, sobrava tempo para o ócio. Assim, cada vez mais pessoas se interessavam pelo livro e a leitura. Aos poucos, com a diminuição do analfabetismo, deu-se conta de que não era suficiente saber ler para participar do conteúdo do livro, pois a leitura da obra exige um nível cultural mais elevado e supõe a aquisição de hábitos de leitura, resultando que os leitores de livros precisavam de instrução secundária ou superior. Dessa forma, a leitura continuou centrada nos níveis mais altos da sociedade. Somente no século XX aconteceu a explosão do livro, juntamente com o desenrolar de outros meios de comunicação. Foram precisos quatro séculos para que o livro chegasse ao papel de comunicação. É certo que o grau de instrução de uma nação é influenciado pelo nível de vida de seus habitantes, pois é entre os níveis de renda mais elevados que também se encontra o maior consumo de livros. Robine (1974) destaca que, nos países de Terceiro Mundo, a situação continua parecida com aquela do século XIX, com o livro acessível somente às classes mais altas da sociedade.

Sílvio Romero, no texto A literatura e a sociedade no Brasil (1978), salienta que "o estado de pauperismo de um povo influi diretamente na formação de sua literatura (...) o homem antes de ser um ente histórico é um indivíduo biológico", sendo sua principal preocupação o "primo vivere" (ROMERO, 1978, p.11). Para o autor, "a grande pobreza das classes populares, a falta de instrução e todos os abusos de uma organização civil e social defeituosa, devem ser contados entre os empecilhos ao desenvolvimento da nossa literatura" (ROMERO, 1978, p. 14). Para 
uma sociedade paupérrima, como a brasileira, com o povo que mal tem o que comer, resta fôlego para pensar em literatura e leitura? Sobre isso o historiador e crítico literário destaca:

\begin{abstract}
A mais completa indiferença pelo que é produto intelectual brasileiro aqui reina. Os poucos que têm a moléstia das letras e se esforçam para aviventar o pensamento nacional ao contato das grandes ideias do mundo culto, sem afogar esta nacionalidade nascente num pélago de imitações sem critério, esses não são ouvidos pelo geral do público, ocupados a bater palmas ao último folhetim ou aos últimos versinhos chegados de Lisboa ou de Paris... (ROMERO, 1978, p. 13)
\end{abstract}

Para pensar a história da literatura no Brasil, o estudioso faz uma correlação entre literatura e sociedade, propondo o desenvolvimento da consciência intelectual do brasileiro, trazendo-o para as fontes locais de inspiração e deixando de lado a imitação estrangeira. Por isso, para pensarmos a formação da literatura e leitura no Brasil, temos de pensar como se deu o processo de formação da nossa sociedade e lembrar dos fatores históricos que influenciaram a cultura nacional do colonizado.

Os portugueses, ao tomarem posse das terras brasileiras, estavam interessados somente no que a colônia tinha a oferecer de matéria-prima destinada à comercialização. Para tanto, fixaram aqui uma população encarregada apenas do cultivo, coleta e comercialização dos produtos tropicais. Para isso, segundo Zilberman (1991), não era necessário um sistema educacional, tarefa essa que foi destinada aos jesuítas. Não existiu, desde os primórdios, uma política de difusão do saber. Tínhamos, sim, uma restrição à importação de livros, ausência de livrarias e a proibição da imprensa. O historiador e crítico de literatura Veríssimo (1977) destaca que os portugueses não trouxeram nada do seu movimento literário para o Brasil. O português colonizador, que veio para o Brasil, não pertencia às classes intelectuais, era o povo da classe mais baixa, preocupado apenas com a sobrevivência, e não com o desenvolvimento cultural da colônia.

Dessa forma, sem a preocupação com o desenvolvimento cultural, até 1808 praticamente não existe a imprensa no Brasil. "Por consequência, ficou difícil a disseminação de práticas de leitura mais intensas e consistentes" (LAJOLO; ZILBERMAN, 1996, p. 122). As autoras questionam de que modo poderia ter sido fortalecida uma cultura nacional já que os elementos nativos estavam sendo 
aniquilados, os africanos subjugados e apenas os elementos europeus valorizados. Salientam que, mesmo depois da independência política, em 1822, não se teve um processo de emancipação cultural. É somente por volta de 1840, que o Brasil

\begin{abstract}
passa a exibir alguns traços necessários para a formação e fortalecimento de uma sociedade leitora: estavam presentes os mecanismos mínimos para produção e circulação da literatura, como tipografias, livrarias e bibliotecas; a escolarização era precária, mas manifestava-se o movimento visando à melhoria do sistema; o capitalismo ensaiava seus primeiros passos graças à expansão da cafeicultura e dos interesses econômicos britânicos, que queriam um mercado cativo, mas em constante progresso. (LAJOLO; ZILBERMAN, 1996, p, 18)
\end{abstract}

Foi preciso quase quatro séculos para que o Brasil começasse a pensar sua independência política, econômica cultural e a tomar consciência das mudanças que teriam de ser feitas. Muitos historiadores e críticos apontavam os caminhos a serem seguidos para a emancipação, mas obviamente, essa consciência nacionalista dependia de um processo de maturação que levou muito tempo.

Veríssimo, ao analisar as condições da produção literária no Brasil, em texto de 1902, enfatiza: "o livro é pouco lido, não tem repercussão em nosso meio" (VERÍSSIMO, 1977, p. 56), salvo o jornal, em circunstâncias especiais. O fato é que os povos de cultura latina e católicos leem pouco, ao contrário dos povos protestantes que, através da leitura da Bíblia, adquiriram o hábito da leitura. $O$ autor destaca que os católicos, na infância, não tinham o hábito da leitura e a literatura infantil, "tão rica nos protestantes, é escassa, desvaliosa ou apenas uma mesquinha imitação dos anglo-saxões e germanos" (VERÍSSIMO, 1977, p. 56). Não existiam incentivos para a leitura e o número de analfabetos era alto, somente em torno de dezessete por cento da população brasileira sabia ler, segundo estatística oficial do ano de 1890. O autor reforça: "difícil será, entre os países presumidos de civilizados, encontrar tão alta proporção de iletrados (...) à literatura aqui falta a condição de cultura geral, ainda rudimentar e, igualmente, o leitor e consumidor dos seus produtos" (VERÍSSIMO, 1977, p. 56-57). Ou seja, falta à literatura, o leitor, permanecendo dessa maneira, uma literatura de poucos. A mulher brasileira raramente sabia ler, pois "a leitura the era desaconselhada pelos seus confessores e pelos moralistas" (VERÍSSIMO, 1977, p. 56). O autor cita que 
Dom Francisco Manuel de Melo, fidalgo português, na Carta de guia de casados, exprime o conceito sobre as leituras das mulheres "o melhor livro é a almofada e o bastidor" (VERÍSSIMO, 1977, p. 56). O autor destaca ainda que, na sociedade europeia, a mulher tinha um importante papel na disseminação da literatura, pois, nos salões e festas muitas conversas giravam em torno das leituras. Essas conversas garantiam a difusão do livro e da leitura. Já no Brasil, cabem-lhe somente as habilidades domésticas. É certo que, num grupo, quando duas ou três pessoas vibram com a mesma leitura, de repente elas embarcam nessa conversa, começam a falar nisso, e deixam os outros que estão a escutar morrendo de vontade de procurar esse livro. É preciso salientar que, no modelo burguês de família, a mulher exercia um papel fundamental na educação e preparação das crianças para o mundo adulto. E se, no Brasil, falta à mulher a leitura, falta dessa maneira, também, a influência leitora sobre os pequenos.

De lá para cá, segundo Zilberman (1991), a difusão do livro e da leitura ficou a cargo da escola, que passou por momentos difíceis. Somente após a revolução de 1930 a rede pública de ensino foi ampliada, bem como a privada, e com o tempo passou-se a ter uma educação de melhor qualidade. Com as reformas de ensino, a frequência obrigatória à escola foi aumentada, os conteúdos foram diluídos, comprimiram-se as áreas do conhecimento. "O achatamento da escola pública e o florescimento da rede privada em todos os níveis colaboraram para a perpetuação do processo de elitização do ensino brasileiro" (ZILBERMAN, 1991, p. 49). Nos primeiros momentos, a leitura estava confinada à alfabetização e, secundariamente, associada ao conhecimento da tradição literária que, segundo a autora, não eram consumidos de maneira direta, mas sim, através do principal meio de leitura na escola: o livro didático. Esse só teve êxito porque ainda vigora a dificuldade de acesso ao livro literário. A distância entre o livro literário e o leitor sempre foi grande e o livro didático ocupou esse vazio estabelecido. Para a autora, a política de popularização do livro literário e da leitura tem que ser responsabilidade do poder público, se se deseja uma sociedade democrática e uma escola eficiente ao alcance de todos. Destaca ainda:

A entidade que vai assegurar a integração a um governo de participação popular é a escola; e, segundo sua organização, é a alfabetização que se constitui na alavanca que aciona a aprendizagem como um todo. Logo, é 
a mudança do indivíduo em leitor que, do ângulo individual, oferece o requisito primeiro para atuação política numa sociedade democrática. Para além desse fato, há a exigência, óbvia e irrestrita, de que a sociedade seja autenticamente democrática, e não apenas se autoproclame como tal. (ZILBERMAN, 1991, p. 21)

O livro passou a ser o grande aliado da escola e da família. Dessa maneira, a obra infantil é o principal objeto passível de adaptação durante a ascensão capitalista. A literatura infantil, no Brasil, em seus primórdios, teve a utilização das aventuras clássicas europeias, que passaram a circular em traduções e adaptações. A adaptação do modelo europeu que chegava ao Brasil, geralmente através de Portugal, não se exerceu apenas sobre o conto de fadas ou clássicos de aventuras, mas "ocorreu também a apropriação brasileira de um projeto educativo e ideológico que via no texto infantil e na escola (...) aliados imprescindíveis para a formação de cidadãos". (LAJOLO; ZILBERMAN, 1984, p. 32). Dentre os problemas com mais urgência, estava o da consciência nacionalista ligada a todas as áreas do pensamento culto. Em 1890, José Veríssimo resumia esse ideal:

\begin{abstract}
Nesse levantamento geral, que é preciso promover o fator da educação nacional, uma das mais necessárias reformas é a do livro de leitura. Cumpre que ele seja brasileiro, não só feito por brasileiro, que não é o mais importante, mas brasileiro pelos assuntos, pelo espírito, pelos autores trasladados, pelos poetas reproduzidos e pelo sentimento nacional que o anime. (...) A maioria dos livros de leitura, se não são estrangeiros pela origem, são-no pelo espírito. (VERÍSSIMO, 1985, p. 5455)
\end{abstract}

É certo que esse nacionalismo dependia de um longo processo. Não é nada fácil para um povo colonizado culturalmente, dependente economicamente de outras nações, encontrar seu caminho. $O$ estudioso salienta que a literatura brasileira estava muito atrasada, sem bons compêndios e com uma grande carência para a leitura para crianças e jovens. Ressalva ainda que se, no século IX e início do século $X X$, não tínhamos o hábito de ler na infância é porque não existiam livros próprios para a idade.

\title{
Uma nova perspectiva para a literatura infantil
}


Quando olhamos para o panorama histórico da Literatura Infantil, é Monteiro Lobato um dos que se empenharam a fundo nessa descoberta da brasilidade, nessa área apontada por Veríssimo como a do "livro de leitura". Isso fica claro nas correspondências trocadas entre Lobato e seu amigo de infância, Godofredo Rangel, observando a realidade a sua volta e pensando como modificála, com o intuito de criar uma literatura infantil genuinamente brasileira. Em carta datada de 08/09/1916, Lobato diz:

\begin{abstract}
Ando com várias ideias. Uma: vestir à nacional as velhas fábulas de Esopo e La Fontaine, tudo em prosa e mexendo nas moralidades. Coisa para crianças. Veio-me, diante da atenção curiosa com que meus pequenos ouvem as fábulas que Purezinha lhes conta. Guardam-nas de memória e vão contá-las aos amigos - sem, entretanto, prestarem nenhuma atenção à moralidade, como é natural. A moralidade nos fica no subconsciente para ir se revelando mais tarde, à medida que progredimos em compreensão. Ora, um fabulário nosso, com bichos daqui em vez dos exóticos, se for feito com arte e talento, dará coisa preciosa. As fábulas em português que conheço, em geral traduções de La Fontaine, são pequenas moitas de amora do mato - espinhentas e impenetráveis. Que é que as nossas crianças podem ler? Não vejo nada. Fábulas assim seriam um começo da literatura que nos falta. Como tenho um jeito para impingir gato por lebre, isto é, habilidade por talento, ando com ideia de iniciar a coisa. É de tal pobreza e tão besta a nossa literatura infantil, que nada acho para a iniciação dos meus filhos. Mais tarde só poderei darIhes $O$ coração de Amicis - um livro tendente a formar italianinhos... (LOBATO, 1955, p. 104)
\end{abstract}

A proposta de Lobato também conversa com a do historiador e crítico Sílvio Romero, que propunha o desenvolvimento da consciência intelectual do brasileiro, trazendo-o para as fontes locais de inspiração e deixando de lado a imitação estrangeira. Se, na infância, os brasileirinhos não leem, será que não é por falta de algo genuinamente brasileiro? Será que não é por falta de mais livros de histórias que os levem a viajar do que livros que querem lhes ensinar alguma moral, bons costumes, com intuito pedagógico? O desejo de escrever histórias onde os pequenos leitores pudessem "morar" é expresso em outra carta de Lobato a Rangel, em maio de 1926:

Ando com ideias de entrar por esse caminho: livros para crianças. Do escrever para marmanjos já me enjoei. Bichos sem graça. Mas para as crianças um livro é todo um mundo. Lembro-me de como vivi dentro do Robinson Crusoé de Laemmert. Ainda acabo fazendo livros onde as crianças possam morar. Não ler e jogar fora, sim morar, como morei no Robinson e n'Os Filhos do Capitão Grant. (LOBATO, 1955, p. 292-293). 
Lobato preocupava-se com os livros de leitura para as crianças, observava a realidade a sua volta e estudava um meio de modificá-la. Romero, Veríssimo e Lobato nos dão a exata dimensão do que ocorria a respeito da sociedade, do livro e da leitura no Brasil no final do século XIX e início do XX. Lobato, além de indicar os caminhos que deveriam ser trilhados, "foi um dos que se empenharam a fundo nessa luta pela descoberta e conquista da brasilidade ou do nacional" (COELHO, 1991, p. 226). Para Lobato, não bastava apenas a tradução de obras estrangeiras, era preciso, sim, adaptá-las à realidade do leitor infantil brasileiro, bem como criar novas histórias com as quais o leitor brasileiro se identificasse e reconhecesse seu país. O desejo de Lobato foi realizado e seus livros logo foram traduzidos no exterior, foram lidos e amados também por crianças não brasileiras, "prova de que Lobato conseguiu fixar o nacional, em sua essência humana e universal - daí sua facilidade com que transpôs as fronteiras do país" (COELHO, 1991, p. 228).

Podemos considerar Lobato como "o divisor de águas que separa o Brasil de ontem e o Brasil de hoje" (COELHO, 1982, p. 354). Foi ele quem encontrou o caminho de que a Literatura Infantil estava necessitando. Ele conseguiu romper com o racionalismo tradicional, com o modelo pedagógico, com o círculo de dependência dos padrões europeus, criando assim, uma literatura autônoma. Para Zilberman (1981), Lobato constrói uma realidade ficcional condizente com a realidade brasileira e com o leitor de seu tempo, ao inventar o Sítio do Pica-pau Amarelo. Em muitos casos, faz o aproveitamento de personagens fantásticas do folclore e da mitologia clássica, empregando as crianças como heróis, o que possibilita a sua identificação com o leitor. Com Lobato, temos a adaptação como principal recurso para a atualização do acervo literário infantil. A inclusão do sítio, com os serões de Dona Benta, nos quais eram contadas diversas histórias, funcionava como base ficcional para a adaptação de qualquer obra literária.

Dentre os muitos textos que Lobato adaptou, tomemos aqui o exemplo de Peter Pan (1930), história narrada por Dona Benta, durante seus serões. A curiosidade inicial das crianças, em conhecer a história do menino da Terra do Nunca, provém de episódios anteriores na obra Reinações de Narizinho. Dona Benta desconhece a história de Peter Pan (1911), de James Barrie, e escreve a uma livraria de São Paulo, solicitando o livro. Para poder transmiti-la aos netos em 
uma linguagem oral, primeiramente a avó lê a obra, ainda no idioma inglês, visto que a edição original de Barrie separa a adaptação de Lobato em menos de 20 anos. Essa relação de aquisição da obra original para, secundariamente, ser contada aos ouvintes do sítio, também acontece com $O$ irmão do Pinóquio, uma adaptação da obra clássica Pinóquio, do italiano Carlo Collodi. Já em Dom Quixote das crianças, a narrativa acontece quando Emília descobre, na estante de Dona Benta, um livro que nunca tinha visto: Dom Quixote de La Mancha. A avó começa a leitura para os meninos, mas eles tropeçam no estilo do autor, muito rico, mas meio difícil. Então, ela decide interromper a leitura e conta a história com suas próprias palavras.

Assim, a partir da oralidade, na voz de Dona Benta, a adaptação dos clássicos é levada aos ouvintes do Sítio e também aos pequenos leitores. Aqui, nos deteremos na obra Peter Pan. Durante a narrativa, as explicações de Dona Benta servem para aproximar os fatos narrados do cotidiano no qual se conta a história, com a preocupação de que os ouvintes assimilem a obra inglesa, tornando o mundo de Peter Pan mais próximo ao dos ouvintes do sítio e dos leitores brasileiros. A narrativa é interrompida a todo momento, para contextualizar a história e esclarecer nomes e situações que fazem parte de outra cultura, tais como o termo nursey:

Nursey (pronuncia-se nârseri) quer dizer em inglês, quarto de crianças. Aqui no Brasil, quarto de criança é um quarto como outro qualquer e por isso não tem nome especial. Mas na Inglaterra é diferente. São uma beleza os quartos das crianças lá, com pinturas engraçadas rodeando as paredes, todos cheios de móveis especiais, e de quanto brinquedo existe. (LOBATO, 1995, p. 8-9)

A liberdade dada aos pequenos oportuniza críticas às atitudes dos personagens de Barrie, nesse caso, crítica à personagem Peter Pan, no primeiro contato com a menina Wendy:

- Oh, não se ofenda, Wendy! Eu tenho esse defeito. Sou gabola de nascença. Quando qualquer coisa de bom me acontece, ponho-me sem querer a contar prosa. Seja boa. Perdoe-me. Reconheço que uma menina vale mais do que vinte meninos.

- Isso também não! - protestou Pedrinho. - Só se é na Inglaterra. Aqui no Brasil um menino vale pelo menos duas meninas.

- Olhem outro gabola! - exclamou Narizinho. - Vovó já disse que louvor em boca própria é vitupério. (LOBATO, 1995, p. 12-13) 
Os ouvintes emitem opiniões, envolvem-se na história narrada e identificam-se com os personagens, trazendo o conflito de Wendy e Peter Pan para dentro da sala onde estão ouvindo a história. Ao final do primeiro dia do serão, Narizinho elogia a história narrada e a compara com outros contos de fadas conhecidos:

- Estou notando isso, vovó, disse ela. Nas histórias antigas de Grimm, Andersen, Perrault e outros, a coisa é sempre a mesma - um rei, uma rainha, um filho de rei, uma princesa, um urso que vira príncipe, uma fada. As histórias modernas variam mais. Esta promete ser muito boa. (LOBATO, 1995, p. 16-17)

Pelo comentário da menina, percebemos também a identificação da ouvinte com uma história mais próxima da sua realidade, não tão distante como as dos contos de fadas. Desse modo, podemos antever a identificação do público leitor com a obra contemporânea, visto que havia sido escrita no mesmo século. Podemos talvez perceber, aqui, aquilo que Lobato, em suas cartas a Godofredo Rangel, destacava como histórias distantes do leitor brasileiro. Não que elas não sejam fundamentais, mas seria preciso trazer ao pequeno leitor algo mais próximo de sua realidade. Conhecer os contos de fadas e clássicos universais era importante para Lobato, mas, de acordo com seu projeto, era preciso contextualizálos. Na seguinte passagem, Pedrinho interrompe a narrativa da avó pois não conhece a expressão sofisticada utilizada por ela:

Certo sábado à noite estavam todos muito ansiosos à espera de Peter Pan, que saíra pela manhã numa expedição cinegética.

- Para aí, vovó! - berrou Pedrinho. Essa palavra esquisita me deixou tonto. Que vem a ser isso?

- Coisa das mais simples, meu filho. Cinegético quer dizer "relativo a caçada". Expedição cinegética significa mesmo caçada.

- Mas se é tão simples dizer caçada, porque vem a senhora com essa terrível complicação? - observou Pedrinho, que era inimigo de palavras difíceis. (LOBATO, 1995, p. 30)

Dona Benta justifica a utilização de palavras difíceis justamente para dar a chance das crianças aprenderem palavras que não conhecem: "- Nesse mundo, Pedrinho, precisamos conhecer a linguagem das gentes simples e também a linguagem dos pedantes, se não os pedantes nos embrulham" (LOBATO, 1995, p.30). Percebemos que Lobato não oculta suas intenções de mostrar ao leitor 
infantil a utilidade do saber, um conhecimento aliado à literatura, talvez ainda resquícios do pedagogismo presente na literatura de até então. Dessa forma, o leitor infantil, ao ler os textos de Lobato, tem também a oportunidade de ampliar seu repertório vocabular, bem como seu conhecimento de mundo.

A narração dos clássicos, feita por Dona Benta, não flui em uma linha contínua devido às interrupções dos ouvintes, bem como não são contadas em um único serão, devido à extensão das histórias. Pelo cenário dos serões, pela oralidade, Dona Benta dá liberdade aos ouvintes para criarem novas aventuras a partir da histórias ouvidas. A narração de Peter Pan vai acontecendo ao mesmo tempo em que a sombra de Tia Nastácia vai desaparecendo. Nesse contexto, Visconde é designado investigador do caso. Narizinho pensa em uma maneira de também ser visitada por Peter Pan e Emília decide construir uma munheca como a do Capitão Gancho, para assustar Tia Nastácia.

Dessa maneira, o cenário do Sítio, com seus moradores, conecta-se com as histórias narradas à moda de Dona Benta, com uma linguagem simples, marca da oralidade, proporcionando um envolvimento e a aproximação com o pequeno leitor. Ao cotejarmos o texto de Lobato ao de Barrie, observamos a supressão de muitas passagens, mudança na fala das personagens, alterações que se tornam necessárias ao projeto de Lobato de ser o mediador entre o público infantil brasileiro e a tradição literária. Observamos, a partir desta adaptação, que Dona Benta tem a função de leitora e, em segundo plano, a de transmissora das leituras. O mesmo acontece com as demais adaptações feitas por Lobato. Assim, as histórias contadas por ela sofrem mudanças em função dos seus ouvintes, da mesma forma que permitem diversos questionamentos, ao mesmo tempo em que o leitor, ao ler os textos do autor, também se questione, levando-o a constituir-se como sujeito crítico.

Tomando outro exemplo de Lobato em Histórias de Tia Nastácia, a narrativa começa com Pedrinho, quando o mesmo descobre que folclore significa a sabedoria do povo em sua oralidade. Pedrinho dá-se conta que Tia Nastácia é o exemplo desse povo que sabe e vai contando um para o outro, mantendo vivas as histórias. 
- As negras velhas - disse Pedrinho - são sempre muito sabidas. Mamãe conta de uma que era o verdadeiro dicionário de histórias folclóricas (...). Todas as noites ela sentava-se na varanda e desfiava histórias e mais histórias. Quem sabe se Tia Nastácia não é uma espécie de Tia Esméria?

Foi assim que nasceram as Histórias de Tia Nastácia. (LOBATO, 1992, p. 8)

Muitas das histórias que Tia Nastácia contava para os pequenos, foram recontadas por Lobato, a partir dos registros de Romero: "- Onde o tal Sílvio Romero pegaria essa história? (...) - Ele fez um trabalho muito interessante, que publicou com o nome Contos populares do Brasil. Ouvia as histórias das negras velhas e copiava-as direitinho" (LOBATO, 1992, p. 56). Aqui, percebemos que Lobato dá crédito ao trabalho de Sílvio Romero, reiterando a importância de sua coletânea. Da mesma maneira que com a obra Peter Pan, as crianças do Sítio interrompem a narrativa e manifestam opiniões, a passagem seguinte refere-se ao conto João $e$ Maria: “- Na versão de Andersen - disse Narizinho - não há negro nenhum, nem nada de três cães. O povo aqui no Brasil misturou a velha história de Joãozinho e Maria com outra qualquer, formando uma coisa diferente" (LOBATO, 1992, p. 55). Lobato confere a Tia Nastácia o papel de narradora dos contos do folclore brasileiro. Para Lajolo e Zilberman (1996) seu modelo é exemplar, pois transfere, para a literatura, a figura que fazia o papel da transmissão folclórica. Assim, o autor parece sugerir um caminho interessante na formação de leitores: recorre à tradição primitiva da narração e audição oral, permitindo as manifestações dos ouvintes, que são também participantes, partilhando o espaço e o tempo. $O$ receptor das narrativas, ou seja, a criança, ao ter vez e voz na narrativa, também percebe seu lugar na sociedade, constituindo-se como sujeito social. Dessa maneira, Lobato tira a ideologia do mais forte sobre o mais fraco, o adulto como detentor exclusivo do conhecimento.

Lobato, a partir do seu modelo de adaptação, estabelece novas diretrizes para a ficção infantil brasileira, pois rompe com os modelos até então vigentes, lançando uma nova literatura, em que o principal sujeito era o leitor. A preocupação de Lobato foi com a diversão das crianças através da leitura, e não com a pedagogia, conseguindo, assim, mudar a tradição ultrapassada da literatura para as crianças, vigente até então. Ao adaptar diversas obras, trazer contos populares, bem como criar histórias genuinamente brasileiras, incorporando as narrativas ao 
espaço físico do Sítio do pica-pau amarelo, Lobato consegue ter êxito em seu projeto.

Ao analisarmos a produção de Lobato, outro ponto que devemos lembrar é em relação à falta de editoras que Sílvio Romero destaca: "não há editores nem leitores para obras nacionais". (ROMERO, 1978, p. 15). A fim de dar continuidade a seu projeto de uma nova literatura para os brasileiros, Lobato teve que criar sua própria editora, a Monteiro Lobato \& Cia. Somente dessa maneira é que conseguiu publicar as obras que desejou, visto o tamanho da dificuldade de publicação de livros no Brasil.

O sucesso de Lobato, entre os leitores infantis e juvenis, decorreu de um fator decisivo: "eles se sentiam identificados com as situações narradas; sentiamse à vontade dentro de uma situação familiar e afetiva, que era subitamente penetrada pelo maravilhoso ou pelo mágico, com a mais absoluta realidade" (COELHO, 1991, p. 227). Para a autora, Lobato fundiu o real com o maravilhoso em uma única realidade, fez o mesmo que Lewis Carroll, em Alice no país das maravilhas, na Inglaterra, 50 anos antes. O maravilhoso passa a integrar o real, o inventado passa a ter voz de verdade, as personagens reais convivem com as personagens inventadas, existindo com a mesma verdade dentro do universo criado por Lobato, esse universo onde o leitor brasileiro tem "morado", como o próprio Lobato o fez, em sua infância, ao ler muitos livros, livros que ele sonhou escrever iguais, conforme desejo expresso nas cartas ao amigo Rangel, e conseguiu.

Se José Veríssimo, ao fazer um levantamento historiográfico da situação da literatura brasileira, no ano de 1890, aponta que faltam ao leitor infantil livros de leitura, bem como o próprio Monteiro Lobato salienta que faltam histórias onde os pequenos pudessem "morar", podemos perceber que, a partir das obras lobatianas, esse panorama toma novos rumos. Monteiro Lobato abre portas para constituir uma literatura genuinamente brasileira para os pequenos leitores e, juntamente com ele, surgem muitos outros escritores que elaboraram seus modelos narrativos e heróis os quais fundaram um universo imaginário peculiar que se encaminha em duas direções principais: "de um lado, reproduz e interpreta a sociedade nacional", com um espaço prioritário de representação: a ambientação rural; "de outro lado, dá margem à manifestação do mundo infantil, que se aloja melhor na fantasia, e não 
na sociedade" (LAJOLO e ZILBERMAN, 1984, p. 67). De ambos os modos enraízase uma literatura mais criativa para o leitor infantil brasileiro, diferentemente da cópia europeia. Ao ambientar as narrativas com o espaço e personagens da cultura popular brasileira, permitiu-se uma aproximação ao universo do pequeno leitor.

Dessa forma, abrem-se, a partir de Monteiro Lobato, muitos outros caminhos a serem percorridos ao olharmos a historiografia do livro e da leitura infantil no Brasil. A partir dos anos 1970, durante o período da ditadura no Brasil, temos o chamado boom da literatura infantil que, através de uma linguagem simbólica, transitava "pelos múltiplos sentidos e pela pluralidade de leituras" (MACHADO, 2011, p. 204), percorrendo trilhos mais tênues, pois, a censura obrigava os artistas a serem sutis e discretos. A literatura infantil foi muitas vezes 0 caminho encontrado para a denúncia da tirania, uma vez que as dificuldades com a censura, enfrentadas pela imprensa, pela música popular, cinema, teatro ou pela literatura para os adultos, eram muitas. "Esse tempo de censura nos ensinou a escrever com mais espessura e ensinou nosso público a ler com inteligência e cumplicidade" (MACHADO, 2011, p. 205). A autora reforça que, diante dessas circunstâncias, e já libertados das fortes amarras do didatismo e do pedagogismo, surge uma literatura infantil de diferentes gêneros, mais rica em efabulação e enriquecida por recursos de realismo e fantasia, proporcionando uma leitura também sem amarras, sem preocupação em ensinar algo, proporcionando ao leitor infantil o verdadeiro prazer de ler. À medida em que essa literatura de tom didático ganha ares poéticos, surge também, no final do século $X X$ e início do século $X X I$, um movimento de ilustradores de livros infantis, uma reflexão sobre seu processo criativo e sobre os resultados por eles alcançados. Uma proposta para a ilustração brasileira também romper as amarras com os modelos europeus, uma luta pela representatividade da cultura brasileira estar também na ilustração, uma vez que, antes de aprender a ler palavras, lemos imagens.

Assim sendo, a linguagem literária "trata-se não de uma linguagem, mas de um diálogo de linguagens" (BAKHTIN,1998, p. 101), logo, é um fenômeno pluriestilístico, plurilíngue e plurivocal. Esses variados códigos linguísticos, visuais, sociais e culturais estão organizados de maneira a atribuir sentidos ao âmbito ficcional. No universo infantil, o texto verbal, a ilustração e o projeto gráfico juntos formam a unidade da obra. Esse espaço plural do texto literário articula a 
imaginação e estabelece pontes entre as diferentes áreas: entre a literatura e a psicologia, a literatura e as artes visuais, a literatura e a educação, a literatura e a música, entre outros campos.

Atualmente, o livro infantil está altamente atrelado à imagem, ou seja, à ilustração. Texto e ilustração juntos como constituição de um objeto único. "O livro é um objeto de arte, um objeto estético. (...) o livro sensibiliza, desenvolve o espírito crítico, instrumentaliza, é uma ferramenta de formação de pessoas e pode provocar experiências estéticas especiais" (VILELA, 2013, p. 130). O ilustrador defende a ideia de que o livro ilustrado é um "fascinante encontro das artes visuais com a arte da palavra, numa arte narrativa, onde as possibilidades de invenção são muito grandes" (VILELA, 2013, p. 130). A ilustração como suporte da narrativa, como uma obra de arte que apresente uma visão de mundo, não apenas meras imagens para embelezar.

Se, no século passado, Monteiro Lobato sonhava em criar textos onde as crianças pudessem morar, hoje, a oferta de textos disponíveis às crianças está dentro das expectativas do escritor que mudou os rumos da literatura infantil brasileira. Dispomos de muitos escritores e ilustradores preocupados com a qualidade estética do texto literário, fomentando um texto e ilustração que tragam os traços da nossa brasilidade, conversem com nossa cultura e não simplesmente copiem modelos europeus. Hoje, a literatura infantil está cada vez mais presente na sociedade de uma maneira muito própria, ganhando visibilidade no âmbito dos estudos acadêmicos e manifestando-se nas relações culturais contemporâneas, nos mais variados territórios.

\section{THE ROUTE OF THE TRAINING OF READING AND CHILDREN'S LITERATURE IN BRAZIL: A NEW PERSPECTIVE FROM MONTEIRO LOBATO}

Abstract: Children's literature is increasingly present in contemporary society, gaining visibility in the scope of academic studies and manifesting itself in the cultural relations of the most varied territories. It is necessary to understand that children's literature does not appear as art created for the delight and formation of the children's reader, but for a long process of historical construction. It is in the contemporary world that children's literature gains diversified production with ethical and aesthetic quality, as well as studies and literary criticism. To understand this process of children's literature, it is necessary to look at the historical course and to understand how the process of emancipation took place, especially the role of Monteiro Lobato in relation to children's literature, which for a long time was subjugated to a literary subsystem. It is Monteiro Lobato who begins to break with the European moorings and launches a new literature that, on the one hand, interprets Brazilian society and, on the other, is based on fantasy. 
Keywords: Book. Reading. Children's literature. Monteiro Lobato.

\section{REFERÊNCIAS}

BAKHTIN, Mikhail. Questões de literatura e de estética: a teoria do romance. Tradução Aurora Fornoni Bernardini [et al.]. São Paulo: UNESP, 1998.

CHARTIER, Roger. A ordem dos livros: leitores, autores e bibliotecas na Europa entre os séculos XVI e XVIII. Brasília: Editora Universidade de Brasília, 1994.

CHARTIER, Roger. As revoluções da leitura no ocidente. In: ABREU, Márcia (Org.). Leitura, história e história da leitura. Campinas: Mercado das Letras, 1999.

COELHO, Nelly Novaes. Panorama histórico da literatura infantil e juvenil. São Paulo: Ática, 1991.

COELHO, Nelly Novaes. A literatura infantil: história, teoria, análise: das origens orientais ao Brasil de hoje. São Paulo: Global Editora, 1982.

LAJOLO, Marisa; ZILBERNAM, Regina. Literatura infantil brasileira: história \& histórias. São Paulo: Ática, 1984.

LAJOLO, Marisa; ZILBERMAN, Regina. A formação da leitura no Brasil. São Paulo: Ática, 1996.

LOBATO, Monteiro. A barca de Gleyre. São Paulo: Brasiliense, 1955, tomos 1 e 2.

LOBATO, Monteiro. Histórias de Tia Nastácia. São Paulo: Círculo do Livro, 1992.

LOBATO, Monteiro. Peter Pan. São Paulo: Brasiliense, 1995.

MACHADO, Ana Maria. Silenciosa algazarra: reflexões sobre livros e práticas de leitura. São Paulo: Companhia das Letras, 2011.

ROBAINE, Nicole. La lectura. In: ESCARPIT, Robert y otros. Hacia una sociologia del hecho literario. Madrid: Edicusa, 1974.

ROMERO, Sílvio. A literatura e a sociedade no Brasil. In: CANDIDO, Antonio (Org.). Sílvio Romero: teoria, crítica e história literária. Rio de Janeiro: LTC, 1978, p. 11 24.

VERÍSSIMO, José. Das condições da produção literária no Brasil; O movimento intelectual em 1891. In: BARBOSA, João Alexandre (Org.). José Veríssimo: teoria, crítica e história literária. São Paulo: EDUSP, 1977, p. 42-59, p. 261-270.

VILELA, Fernando. O livro infantil hoje e amanhã. In: PRADES, Dolores. Crianças e jovens do século XXI: leitores e leituras. São Paulo: Livros da Matriz, 2013. p. 118-137. 
VERÍSSIMO, José. A educação nacional. Porto Alegre: Mercado Aberto, 1985.

ZILBERMAN, Regina. A literatura infantil na escola. São Paulo: Global, 1981.

ZILBERMAN, Regina. A leitura e o ensino da literatura. São Paulo: Contexto, 1991.

Data da Submissão: 14/04/2019

Data da Aprovação: 13/06/2019

Revista de Letras JUÇARA, Caxias - Maranhão, v. 03, n. 01, p. 174 - 192, ago. 2019| 193 